\title{
MEMAHAMI SENSIONALISME DALAM BERITA TELEVISI: PERSPEKTIF EVOLUSI BIOLOGI
}

\author{
Gentur Agustinus Naru \\ Email: gabrielabimanyu1@gmail.com \\ Institusi: Pasca Sarjana Ilmu Komunikasi Universitas Paramadina \\ Gedung Tempo, Jl Palmerah Barat No.8, Kebayoran Lama, Jakarta Tlp: (021) \\ 79181188 \\ dan \\ Budi Adiputro \\ Email: didietpob@gmail.com \\ Institusi: Pasca Sarjana Ilmu Komunikasi Universitas Paramadina \\ Gedung Tempo, Jl Palmerah Barat No.8, Kebayoran Lama, Jakarta Tlp: (021) \\ 79181188
}

\begin{abstract}
Abstrack
Although there have been many studies regarding sensationalism on television, there have not been enough studies to explain why sensational news always attracts viewers' attention regardless of space or time difference. Encouraged by this background, this research tries to answer the question, "What makes sensational news interesting to television viewers?" Inspired by a biological evolutionary perspective, this article formulates a hypothesis that reads, "Sensationalism can draw the attention of the audience because sensational news arouses the most basic instincts of humans, namely the mode of survival (Gurven, 2017)". In this view, the model has become inherent in humans as a result of the evolutionary process. In other words, this hypothesis also believes that audience interest in sensational news is universal rather than contextual.

This article explores a variety of literature in biology, psychology, and communication to try to answer that hypothesis. In order to that, this article is divided into three main sections. We will first explore the history of sensational journalism on television to show the historicity of sensational topics and techniques on television. Second, we will demonstrate the philosophical roots of an evolutionary biology view that explains the relationship between information stimuli and the workings of the human brain and the basic instincts we have carried since evolution thousands of years ago. Finally, we will show studies that prove empirically how news patterns (both sensational topics and production formats) impact viewing interest.
\end{abstract}

Kata Kunci: Journalism, Media Studies, Cultural Studies 


\section{PENDAHULUAN}

Kompetisi yang sengit antara televisi dan antara televisi dengan media digital telah membuat berita yang diproduksi oleh industri televisi bergeser dari penekanan pada jurnalisme yang memiliki nilai publik mengarah pada jurnalisme yang menghibur. Indikasi dari pergeseran ini adalah intensifikas sensasionalisme dalam berita televisi yang dapat ditemukan dalam satu dekade terakhir. Bila umumnya kita menemukan sensasionalisme dilakukan dalam peliputan beritaberita kriminal, kini gaya sensasionalisme yang sama diterapkan dalam pemberitaan politik (Arief, 2017).

Berita kriminal digolongkan kedalam berita sensasional karena topiknya dan gambar yang seringkali ditampilkan secara vulgar Berdasarkan hasil analisa yang dilakukan (Berkowitz \& Gobetz, 1993;1992), berita kriminal mampu membangkitkan respon neural pada khalayak. Misalnya saja memprovokasi emosi seperti rasa takut, perasaan terasing, maupun luapan rasa gembira. Peliputan yang dramatis mengenai kejahatan juga menimbulkan kesan pada penonton bahwa kejahatan merajalela di sekitar mereka (Septian, 2005).

Studi Yovantra Arief menunjukkan bahwa pada pemilihan kepala daerah Jakarta 2016 yang lalu, liputan politik dikemas dengan gaya sensasional yang menyerupai berita kriminal. Tentu dalam hal ini bukan menghadirkan hiburan dalam bentuk rasa takut yang dramatis melainkan dengan cara mendudukkan politik sebagai sebuah peristiwa menarik. Politik bukanlah peristiwa yang membosankan kala media menghadirkan kisah "kedekatan 
Anies Baswedan dengan ibunya" atau

kisah "Sepatu kesayangan Sandiaga

Uno". "Dalam 10 hari pertama Anies-

Sandi

memegang

tampuk

pemerintahan Jakarta", media

mengubah peristiwa politik

menjadi infotainment yang

mengasyikkandalam apa yang disebut

sebagai politaiment (Arief, 2017).

Dalam contoh berita kriminal

maupun politik sebagaimana

ditunjukkan oleh dua studi di atas,

sensasionalisme dapat didefinisikan

sebagai upaya mempresentasikan

fakta atau cerita dengan tujuan untuk

menciptakan perasaan yang kuat,

seperti kegembiraan, kemarahan, atau

kesedihan (Collindictionary.com).

Definisi ini memuat dua aspek

penting. Pertama, cerita yang dipilih

dan kedua cara menyampaikannya.

Berita konflik misalnya, lepas ia

digambarkan secara biasa saja tetap

akan menarik perhatian penonton karena isunya sendiri adalah sesuatu yang bisa menciptakan emosi yang kuat. Sementara berita politik yang membosankan bisa digambarkan secara dramatis dengan pemilihan sudut pandang, teknis pengambilan gambar, maupun latar musik yang digunakan.

Kecenderungan televisi memuat informasi yang atraktif atau berorientasi pada hiburan adalah akibat dari Market driven journalism. Dengan membuat informasi semakin "sensasional" atau menyerupai tabloid dari waktu ke waktu, terbukti mampu meningkatkan perhatian penonton. (Uribe \& Gunter, 2007).

Kendati

demikian,

sensasionalisme dalam pemberitaan bukan tanpa masalah. Kualitas jurnalisme yang disajikan dengan gaya sensasional kerap dipertanyakan. Kritik umumnya diarahkan pada kegagalan dari jurnalisme sensasional 
untuk menghadirkan berita yang memiliki nilai aksi. Dalam bukunya,

Etika Komunikasi, Haryatmoko mengatakan "Informasi yang benar mencerahkan kehidupan. Ia membantu menjernihkan pertimbangan untuk bisa mengambil keputusan yang tepat" (Haryatmoko, 2007: 19). Penekanan pada emosi dalam pemberitaan sensasional bertentangan dengan semangat ini.

Ambil misalnya kasus pemberitaan politik yang mengisahkan kedekatan Anies Baswedan dengan ibunya. Informasi semacam ini mungkin membangkitkan empati dan mengajak penonton memanusiakan Anies Baswedan. Namun, apakah informasi semacam ini bisa membantu warga negara mengambil keputusan dalam pemilihan umum? Apakah informasi tersebut memberi tahu kita mengenai kualitas kepemimpinan seorang politisi yang hendak mengisi posisi jabatan publik? Tentu tidak. Begitu juga halnya dengan berita kriminal yang fokus pada "kekejaman pelaku" dan detil peristiwa kejahatan yang dilakukan. Berita jenis ini mengalihkan kita dari hal yang lebih penting, yakni aspek hukum dari peristiwa dan bagaimana peran aparat keamanan dalam memastikan hal serupa tidak terjadi lagi.

Berita sensasional kerap disebut sebagai "Junk Food of News". Sebagaimana halnya junk food ia kerap memuat lebih baik lemak ketimbang protein. Lebih banyak remah-remah informasi tak bernilai ketimbang fakta yang penting bagi kehidupan publik. Dengan kata lain, ia adalah musuh dari jurnalisme yang sehat. Berlawanan dengan Jurnalisme yang mendasarkan diri pada apa yang dibutuhkan publik agar dapat berfungsi sebagai warga negara yang 
ideal, jurnalisme senasional mengabdikan dirinya pada keinginan dan selara publik dalam kerangka ekonomi pasar.

Banyak studi telah dilakukan untuk mengkritik sensasionalisme. Di Indonesia sendiri, studi paling baru (2019), bisa kita tenemukan misalnya penelitian bertajuk "Analisis Isi Sensasionalisme Berita Kriminal: Studi Kasus Program I News dan Kompas Sulsel”, yang dilakukan oleh Yuweni Puji Saputri. Studi ini menunjukkan bagaimana modus sensasionalisme dalam berita kriminal di dua stasiun tersebut dilakukan dengan cara " pemilihan kata - kata tertentu pada judul, penggunaan grafis, gambar dan keterangan yang menarik, peminjaman mulut pakar untuk menyampaikan sebuah gagasan, penetapan angle untuk sajian media,dan penggunaan musik"(Saputri, 2019).
Studi di atas adalah kontribusi penting bagi percakapan akademik mengenai sensasionalisme dalam pemberitaan televisi. Ia memberi kita gambaran mengenai strategi editorial dalam pengemasan berita yang sensasional dan menujukkan pada kita dampak dari market driven journalisme terhadap kualitas percakapan publik kita. Tesisnya adalah persaingan media dalam sistem ekonomi pasar mendorong perluasan sensasionalisme dalam media. Meski kami setuju dengan tesis tersebut, kami menilai riset tersebut masih menyisakan lubang dalam analisisnya. Lubang itu adalah mengapa sensasionalisme menjadi alat yang efektif bagi redaksi meraih perhatian penonton? Pertanyaan itulah yang hendak dijawab dalam tulisan ini.

Artikel ini bertujuan mengetengahkan perspektif evolusi 
biologisebagai upaya untuk menjawab

hubungan antara minat menonton televisi dengan gaya jurnalisme yang sensasional. Alasan dibalik pilihan penulis memilih perspektif ini adalah kenyataan bahwa sensasionalisme telah ada jauh dalam sejarah manusia sebelum ekonomi pasar melandasi kerja industri media. Michell Sthepens dalam bukunya "A History of News" mengatakan bahwa sensasionalisme telah ada sejak manusia mulai bercerita. Seks dan konflik adalah dua ciri cerita sensasional yangkerap kita temukan dalam berbagai epos bangsa-bangsa.

Dengan kata lain, Sthepen ingin mengatakan bahwa industri media hanya mengeksploitasi apa yang telah secara primitif ada dalam diri manusia, yakni rasa penasaran yang besar pada konflik, seks, juga kekerasan.
Kami percaya, perspektif yang kami tawarkan dalam artikel ini akan mampu memperkaya khasanah kajian media, khususnya dalam konteks studi sensasionalisme.Secara praktis, perspektif yang kami ketengahkan akan berguna dalam upaya kita membangun literasi media untuk membentengi publik dari terpaan beritaan senasional. Dengan pengetahuan yang mendasar mengenai hubungan antara sifat manusia yang dibawa dari proses evolusi dengan modus dan strategi pengemasan berita sensasional kita akan mampu membangun formula literasi media yang lebih efektif. Dan pada gilirannya akan ia juga berguna dalam mendukung lahirnya ekosistem media yang lebih sehat. Umum diketahui, publik yang kritis akan mendorong terciptanya jurnalisme yang berkualitas. 


\section{METODE}

Artikel ini menggunakan

metode studi pustaka untuk menjawab

pertanyaan

“Apa

yang

membuatberita

sensasional

menarik bagi penonton televisi?".

Metode studi pustaka adalah kegiatan

untuk menghimpun informasi yang

relevan dengan topik atau masalah

yang menjadi obyek penelitian.

Dengan

melakukan studi

kepustakaan, peneliti dapat

memanfaatkan semua informasi dan

pemikiran-pemikiran yang relevan

dengan penelitiannya.

Dalam

melakukan

penghimpunan dan penyeleksian

literatur untuk menjawab penelitian

ini kami berangkat dari hipotesis yang

telah lebih dulu kami rumuskan.

Hipotesis

itu

adalah

"Sensasionalisme mampu menyedot

perhatian penonton karena berita

sensasional menggugah insting paling dasar dari manusia yakni

mode of survival (Gurven, 2017)".

Hipotesis ini kami bangun dari perspektif biologi evolusioner.

Dalam pandangan ini kematian dan seks, adalah dua hal yang selalu membuat manusia terjaga. Ketakutan akan mati meningkatkan kewaspadaan kita terhadap apa yang terjadi di sekeliling kita. Inilah mengapa berita-berita dengan topik seperti bencana, perang, dan pembunuhan selalu menarik perhatian. Jika ketakutan akan kematian melahirkan sikap defensif maka hasrat seksual adalah perpanjangan dari hasrat aktif manusia untuk bertahan hidup (berkembang biak).Dua hal tersebut telah menjadi inheren dalam diri manusia sebagai akibat dari proses evolusi. Dengannya, hipotesis ini juga percaya bahwa ketertarikan penonton 
pada berita sensasional bersifat kami akan mendemonstrasikan

universal alih-alih kontekstual.

Berangkat dari hipotesis

tersebut kami pun menelusuri

berbagai literatur di bidang biologi, psikologi, dan komunikasi. Implikasi dari asumsi bahwa sensionalisme konsisten dengan pandangan evolusi biologis maka konsekuensi logisnya adalah kami pun perlu menelusuri riset-riset yang mencoba memvalidasi pandangan tersebut secara empiris. Dengan kerangka pemikiran yang demikian maka pembahasan dalam artikel ini dibagi menjadi tiga bagian. Pertama, kami akan menelusuri sejarah jurnalisme senasional di televisi untuk menujukkan bahwa sensasionalisme mampu melintasi waktu dan topik. Ini adalah bagian dari upaya menunjukkan sifat universal dari konten sensasional dalam kaitannya dengan minat manusia menonton berita. Kedua, pandangan biologi evolusioner yang menjelaskan hubungan antara stimuli informasi dengan cara kerja otak manusia dan insting dasar yang telah kita bawa sejak evolusi ribuan tahun lalu. Terakhir, kami akan menunjukkan penelitian-penelitian yangmembuktikan secara empiris bagaiman pola pemberitaan sensasional(baik topik maupun format produksinya) berdampak pada minat menonton.

\section{PEMBAHASAN}

Sejarah Sensasionalisme di Televisi: Dari Berita Kriminal ke Politik

Awal mula sensasionalisme di televisi bisa ditemukan semenjak awal berdirinya televisi swasta di Indonesia. RCTI, televisi swasta pertama yang berdiri tahun 1989, adalah pelopor berita kriminal melalui program seputar Indonesia. Seputar 
Indonesia adalah program berita pita"yang kerap disajikan TVRI. pertama yang diproduksi secara in Istilah berita "gunting pita" muncul house oleh televisi swasta, mengingat karena berita produksi TVRI di era Orde Baru, pemerintah umumnyamenayangkan kisah pejabat memiliki regulasi yang melarang pemerintah meresmikan proyektelevisi swasta memproduksi berita proyek pemerintah. Sebagai sendiri. Semua berita televisi kala itu simbolisasi peresmian proyek itu wajib relaydari TVRI. Kebijakan ini ditandai dengan pejabat menggunting adalah bagian dari kontrol ketat pita (Harahap, 2014).

pemerintah Orde Baru untuk menjaga

Berawal dari hadirnya program agar pemberitaan tidak keluar dari Seputar Indonesia sekitar tahun 1990, narasi resmi pemerintah (Kitley, 2001).

Untuk mengatasi kontrol ketat tersebut, RCTI membuat Seputar program sejenis berjudul Serbabineka Indonesia sebagai program berita sekitar tahun 1993. Kehadiran dua feature. Dengan cara ini, Seputar program tersebut dalam industri Indonesia bisa menghindari berita televisi nasionalmemberi penonton politik. Maka, kriminalitas pun sajian berita yang berbeda dengan menjadi resep yang ampuh. Selain TVRI yang tetap konsisten dengan mampu menghindari sensor berita "gunting pita"-nya. Namun pemerintah, ia pun menjadi formula penayangan berita kriminal ini sempat yang mampu memecah kebosanan terhenti selama tiga tahun seiring penonton pada berita "gunting dengan kelonggaran yang diberikan 
pemerintah untuk penayangan berita

di TV swasta. Berita kriminal ditinggalkan karena dianggap tontonan kelas bawah. Berita di TV swasta pun mulai memasuki ranah berita politik, ekonomi dan pemerintahan. Semua TV swasta seolah terpaku dengan berita ini. Bahkan laporan-laporan dari sidang anggota DPR menjadi sajian utama berita TV swasta.

Sajian berita kriminal kembali marak dengan hadirnya Cakrawala ANTV sekitar tahun 1996. Rating program berita Cakrawala yang menyajikan laporan kriminal bisa melampaui angka sepuluh. Stasiun TV lain pun kembali melirik program ini. TPI melalui Lintas 5 pun menggarap berita kriminal secara serius. Para pelaku kejahatan, korban pembunuhan, korban pemerkosaan dan darah berceceran kian menghiasa layar kaca TV swasta dengan hadirnya Program berita kriminal Sergap RCTI dan Buser SCTV tahun 2001. Hingga tahun 2011, puluhan program berita kriminal muncul di layar TV, seperti Patroli, Sidik, dan banyak lainnya(Harahap, 2014).

Lepas dari perbedaan waktu tayang dan stasiun berita-berita kriminal di stasiun-stasiun tersebut memiliki format yang sama. Ciri khasnya adalah menghadirkan gambar-gambar dramatis seperti “adegan polisi berkejaran dengan pelaku kriminal", "gambar kebakaran hebat", atau "wajah pelaku kejahatan yang penuh luka dihakimi massa". Hal ini masih ditambah oleh musik latar yang memberikan efek dramatis dari gambar yang ditampilkan dilayar.

Hingga saat ini, programprogram kriminal masih menghiasi layar kaca. Salah satu program kriminal yang cukup mendapat perhatian penonton adalah 86 yang 


\section{MEMAHAMI SENSIONALISME DALAM BERITA TELEVISI:}

PERSPEKTIF EVOLUSI BIOLOGI

tayang di Net TV. Berbeda dengan

program-program

kriminal

pendahulunya, 86 hadir dengan model

baru yang merupakan peniruan atas

program sejenis di Amerika Serikat.

Format yang dipilih 86 adalah embed

journalism, yaitu sebentuk jurnalisme

yang mengikuti subjeknya secara

terus-menerus, dalam hal ini polisi

untuk mendapatkan gambar dari

proses bagaimana polisi menindak

perilaku kriminal. Di luar model

peliputannya, apa yang kita lihat di

layar masih sama dengan proram-

program pendahulunya, yakni gambar

dramatis, kisah yang mencekam, dan

banyak lainnya.

Seiring dengan perkembangan

waktu, sensasionalisme juga kita temukan dalam berita di luar topiktopik khas sensioanlisme seperti politik. Studi Kartika Octaviana (2008), menemukan bahwa program berita siang di TV One dan Metro TV memuat kisah-kisah sensasional.

Umum dikeahui program berita siang adalah berita yang dikemas dalam berbagai topik, mulai dari ekonomi, politik, kriminalitas dan lainnya sebagainya. Studi ini menemukan sebuah fakta "di Kabar Siang TV One, pengemasan topik non sensasional terkadang lebih sensasional ketimbang topik sensasional" (Octaviana, 2008: 91). Peneliti menduga hal ini terjadi karena berita yang secara topik non sensasional kerap kali dirasa membutuhkan teknik pengemasan yang lebih sensasional untuk menarik perhatian penonton. Bagi Oktaviana ini menjadi masuk akal karena pada 2008, saat studi ini dilakukan, TV One adalah televisi berita pendatang baru yang tengah berkompetisi dengan Metro TV. Situasi ini dinilai memicu redaksi dan manajemen TV One untuk menggunakan teknik 
pemberitaan sensasional guna relevansinya dengan pemilihan

memenangkan perhatian publik dari kompetitornya, Metro TV.

Studi Oktaviana juga diperkuat

oleh penelitian Urip Mulyadi bertajuk

“Tabloidisasi Pemberitaan Mengenai

Pemilu Presiden 2014 Pada Program

Berita "Headline News" Metro TV".

Mulyadi menemukan bahwa peliputan

Metro TV atas calon presiden Jokowi

kala iu menggunakan model

pemberitaan yang sensasional. Hal ini

antara lain ditandai dengan:(1)

Personalisasi yang ditunjukkan

dengan orientasi pemilihan topik

berita yang lebih bernilai personal

dibandingkanpublik,

Sensasionalisme, pemberitaan yang

dengan sengaja disampaikan secara

provokatif atau dimanipulasi untuk

"memukau" atau menarik perhatian

pemirsa, (3) Trivialisasi,

denganmenyajikan data-data yang

unik namun tidak memiliki umumpresiden 2014.Hasil penelitian

ini menunjukkanbahwa Metro TV

melakukan tabloidisasi pada berita

mengenai Pemilu Presiden 2014

dalamprogram berita Headline News

(Mulyadi, 2015).

Lepas dari perbedaan waktu maupun topik pemberitaan senasionalisme telah membuktikan bahwa ia mampu bertahan dan menjadi formula yang ampuh guna menarik perhatian konsumen berita. Pertanyaannya kemudian, apa sebabnya?

\section{Senasionalisme dalam perspektif} Evolusi Biologis: The Limited

\section{Capacity Model}

Salah satu sarjana yang coba menjawab pertanyaan mengapasa sensasionalisme mampu melintasi waktu, geografi, dan medium adalah Shoemaker. Ia beragumen proses evolusi telah membuat manusia 


\section{MEMAHAMI SENSIONALISME DALAM BERITA TELEVISI: \\ PERSPEKTIF EVOLUSI BIOLOGI}

mewarisi genetika yang yang berkaitan dengan fungsi

memungkinkan otak untuk secara reporduksi (sex).

terus menerus memonitor lingkungan

demi menghindari ancaman

(Shoemaker, 1996). Otak kita secara

rutin memonitor hal-hal yang tidak

lazim seperti bencana, perang, atau

bahkan ide-ide radikal. Meski, dunia

kita telah jauh lebih aman dari era di

mana nenek moyang kita hidup,

manusia modern masih melakukan

hal yang sama dengan pendahulunya.

David dan McLeod

mengatakan bahwa keberlangsung

hidup generasi berikutnya adalah

faktor penting yang terus menjaga

insting manusia untuk memonitor

lingkungannya. Pandangan terakhir

yang disampaikan David dan McLeod

menunjukkan bahwa tidak hanya

ancaman yang memotiviasi manusia

untuk memonitor lingkungan

disekitarnya, melainkan juga hal-hal
Akar filosofis dari pandangan

yang dikemukakan baik oleh

Shoemaker maupun McLeod adalah biologi evolusioner. Berbeda dengan psikologi sosial yang kerap menaruh perilaku manusia dalam konteks historis dan budaya, perspektif biologi evolusioner memahami perilaku manusia sebagai sesuatu yang universal sebagai hasil dari proses evolusi. Dalam pandangan ini psikologi manusia adalah hasil adaptasi yang dirancang oleh seleksi alam untuk menyelesaikan tantangan hidup di masa lalu evolusi kita. Sama seperti halnya mata vertebrata yang dirancang oleh seleksi alam untuk merespons cahaya dan struktur permukaan objek, begitu juga halnya sistem perilaku manusia dirancang untuk menghadapi tantangan alam yang kompleks. Kehandalan 
memonitor lingkungan menjadi waktu tertentuwaktu (Bradley \& modal penting dalam bertahan hidup. Hitch, 1974; James, 1890). Sama seperti halnya makhluk dengan Keterbatasan ini membuat otak kemampuan visual yang sangat manusia harus melakukan seleksi atas canggih lebih mungkin bertahan terpaan informasi yang diterimanya. dalam proses evolusi karena mampu Dalam situasi di mana stimulus menavigasi dunia tiga dimensi, sistem informasi begitu besar, maka otak perilaku manusia juga berfungsi secara natural akan memproses untuk meningkatkan kemampuan informasi yang menonjol dan biologisnya demi mempertahankan mengabaikan informasi yang kurang dan merebut sumber daya sosial, menonjol (Handy, Hopfinger, \& seperti seks dan status sosial.

Dalam upaya memutuskan Mangun, 2001).

Pandangan diatas lebih jauh perilaku seperti apa yang mesti dipilih dikembangkan dalam teori Limited dalam satu situasi tertentu, informasi Capacity Model. Ada tiga hal yang menjadi modal yang penting. ditambahkan oleh teori ini dalam cara Informasi adalah bahan baku bagi bagaimana kita memahami cara kerja proses yang terjadi di otak manusia otak manusia dalam memproses untuk membuat keputusan. Inilah informasi. Pertama, keputusan mengapa ia signfikan. Kendati mengenai mana informasi yang demikian, seperti hal komputer, kerja dipilih untuk diproses dalam otak bisa otak manusia amatlah terbatas. Otak terjadi secara sadar maupun tidak. Ini hanya dapat memproses sejumlah bergantung pada stimulus informasi kecil informasi di lingkungan pada yang diterima dan tujuan dari setiap 
individu. Sebuah informasi bisa saja secara tidak sadar diproses otak kala informasi itu mampu menonjol diantara banyak informasi lain. Dalam gestalt theory misalnya otak manusia cenderung memberi lebih banyak perhatian pada visual yang memiliki bentuk unik diantara bentuk-bentuk lainnya (menonjol) atau padagambar memiliki kedekatan dengan pengalaman manusia yang mempersepsinya.Dengan kata lain, jenis-jenis stimulus informasi tertentu dapat secara otomatis menarik otak manusia untuk langsung memprosesnya.

Dalam psikologi kita juga mengenal istilah subliminal message. Ia adalah pesan yang disampaikan dalam tempo tinggi untuk melampaui kesadaran kritis manusia. Pesan-pesan semacam ini bisa kita temukan antara lain dari model promosi embeded. Iklan coca-cola misalnya dapat muncul dalam salah satu adegan di sebuah film tanpa secara langsung di iklankan. Para ahli marketing bersepakat bahwa subliminal message bekerja bila dilakukan dengan repitisi yang tinggi. Studi menunjukkan mereka yang terkena terpaan pesan subliminal dalam tingkat yang tinggi menyimpang memori lebih baik mengenai produk yang diiklanan dibanding mereka yang tidak(Greenwald, Spangenberg Pratkanis, dan Eskanazi, 1991). Catatan penting dalam hal ini adalah informasi disampaikan kala manusia dalam kondisi lengah (menikmati film) dan tidak menyadari terpaan iklan yang ada di dalamnya.

Dalam situasi di mana manusia memiliki tujuan dan kesadaran logisnya tengah terjaga tentu konteksnya akan sama sekali berbeda. Dalam situasi demikian proses penyeleksian informasi akan lebih 
banyak ditentukan oleh motivasi sadar dan didasari oleh tujuan mansia

manusia. Dalam Uses and yang menerimanya secara universial

Gratification theory misalnya, dalam di dorong oleh dua motivasi utama kondisi normal manusia cenderung yang dikembangkan selama masa mengakses media dengan tujuan evolusi untuk memfasilitasi perilaku untuk mencari kesenangan dan bertahan hidup. Dua motivasi itu kegunaan. Inilah mengapa banyak adalah kehendak memenuhi dari kita kerap melewati iklan kala kebutuhan biologis dan menghindari kita sedang asyik menonton video ancaman. Manifestasi dari dua favorit kita di youtube. Artinya motivasi tersebut dapat ditemukan pilihan informasi ditentukan oleh dalam berbagai aktivitas yang tujuan individu ketimbang terpaan menghasilkan "gairah" (intensitas yang kuat dan melintas ambang batas atau kegembiraan), valensi (positif kesadaran manusia. Pilihan keputusan atau negatif), dan dominasi (atau yang didorong oleh tujuan individu kontrol; Bradley, 2007a; Bradley \& dan pengetahuan sebelumnya disebut Lang, 1994; Bradley, Codispoti, sebagai top-down,sedangkan yang Cuthbert, \& Lang, 2001).Apa yang didorong oleh fitur stimulus yang dimaksud dengan informasi yang menarik perhatian disebut bottom-up menggairahkan adalah informasi (Desimone \& Duncan, 1995; Kastner seperti sex, musik, film dan banyak \& Ungerleider, 2000; Treisman \& lainnya yang mendorong semangat Gelade, 1980).

hidup.Sedangkan valensi adalah nilai Dalam Limited Capacity Model, $\quad$ sebuah informasi. Jika kita menilai seleksi informasi yang diterima secara sebuah informasi bernilai postif, maka 
kita akan cenderung memberi dua sistem motivasi memiliki pola sumberdaya kognitif yang besar untuk yang unik dalam menanggapi memprosesnya ketimbang yang tidak. peningkatan intensitas stimulus. Saat Terakhir, yang dimaksud dengan istirahat, nafsu biologis lebih dominasi atau kontrol adalah kita diaktifkan daripada motivasi cenderung memberi perhatian pada menghindari ancaman. Perbedaan informasi yang mampu membuat kita dalam aktivasi ini disebut offset mengontrol lingkung tempat kita positif (Cacioppo \& Gardner, 1999; hidup. Misalnya, informasi mengenai Ito \& Cacioppo, 2005). Karena modus-modus kejahatan, lokasi biasa motivasi memenuhi kebutuhan terjadi kejahatan, dan banyak lainnya biologis diaktifkan saat istirahat (di akan membuat kita menentukan cara luar aktivitas produktif), stimulus bagaimana kita menasehati anak atau postif seperti film yang mengandung menentukan jalan pulan dari kantor. adegan sex atau iklan yang Dengan begitu, kita merasa punya mempromosikan makanan akan lebih navigasi untuk memahami realitas merangsang pengalokasikan sumber yang tidak menentu.

kognitif daripada rangsangan negatif

Secara umum, stimulus yang (ancaman). Sebaliknya, di situasi merangsang dua motivasi tersebut terjaga dalam aktivitas yang seperti (kebutuhan bilogis dan menghindar kerja, kuliah, dan banyak lainnya dari ancaman) mendorong manusia stimulus negatiflah yang merangsang untuk menggunakan lebih banyak manusia mengaktivasi sumber daya sumber daya kognitif dibanding yang kognitif. Meski secaram umum, tidak. Namun, masing-masing dari Limited Capacity Model percaya 


\section{MEMAHAMI SENSIONALISME DALAM BERITA TELEVISI: \\ PERSPEKTIF EVOLUSI BIOLOGI}

bahwa stimulus negatif yang bahkanbukan merupakan bentuk

mendorong kegelisahan, ketakutan, representasi penuh dari kenyataan, ataupun perasaan negatif lain mampu tidak mengubah fakta bahwa otak merangsang lebih jauh aktivitas otak manusia memprosesnya dengan cara manusia ketimbang stimulus positif. yang sama.Ini didasarkan pada asumsi (Bradley et al., 2001; Cacioppo, bahwa otak manusia telah berevolusi Gardner, \& Berntson, 1999; Lang et lebih dari ratusan ribu bertahun-tahun al., 1997).

dan belum mengembangkan

\section{Terakhir, Limited Capacity}

Model juga mengatakan bahwa fiturfitur teknologi mampu menciptakan sensasi yang memancing reaksi sama pada otak manusia seperti halnya stimulus yang dialami langsung. Jika menyaksikan kecelakan secara langsung otomatis mengaktivasi otak kita untuk mengalokasikan sumber daya kognitif yang besar, maka hal yang sama juga bisa terjadi kala kita menyaksikan berita kecelakan atau adegan aksi di film. Lepas dari fakta bahwa dunia yang dimediasikan adalah hasil produksi yang kadang melibatkan dramatisasi atau mekanisme untuk melakukan pemilahan secara cepat dan andal antara persepsi fenomena dan fenomena yang dimediasi secara digital di 'dunia nyata' (Reeves \& Nass, 1996). Seperti halnya dalam keseharian, otak manusia akan memberikan perhatian lebih pada apa yang menonjol di media. Sebuah informasi yang diproduksi mengikuti cara kerja otak manusia akan lebih mungkin mendapat perhatian ketimbang yang tidak. (Bailey, 2015; Bradley, 2007a; Lang \& Bailey, 2015) 
Fitur Sensasionalisme dalam Berita

Televisidan Dampaknya pada

\section{Sensori Manusia.}

Jika pada bagian sebelumnya

kita telah banyak membicarakan apa

yang secara alamiah memicu sensasi

di kepala manusia, maka dibagian ini

kita akan membicarakan aspek

produksi televisi yang memungkinkan

cerita diubah jadi sensasional.

Berangkat dari asumsi bahwa media

mengkonstruksi realitas, maka sensasi

yang pada awalnya dipahami melulu

sebagai aspek kisah-kisah yang

menggugah insting bertahan hidup

manusia bisa di ekstrak elemen-

elemennya kemudian di inkorporasi

dalam modus produksi media lewat

teknologi audio dan visual. Inilah

yang disebut dengan embedded

sensationalism (Slatery dan Hakanen,

1994). Contoh dari embedded

sensationalism adalah seperti yang

kita saksikan dalam berita politik di pemilu. Bagaimana berita mengenai

politik atau politisi yang umumnya

tidak secara internal sensasional

diubah lewat serangkaian teknik

produksi untuk menciptakan efek yang sama.

Salah satu modus produksi "embedded sensationalism" bisa kita pahami dalam studi Henriks Vettehen. Penelitiannya mengenai berita-berita politik selama pemilu di beberapa negara Eropa menghasilkan sebuah konsep yang disebut sebagaivivid story telling (cara penulisan cerita yang vulgar). Vivid story telling bisa didefinisikan sebagai informasi yang menarik secara emosional, konkret sekaligus memprovokasi imajinasi, dekat secara sensori, ruang, maupun waktu (Vettehen, 2005). Vettehen percaya berita yang dikemas dengan pendekatan vivid story telling secara universal akan menarik dan menyedot perhatian penonton. Contoh dari 


\section{MEMAHAMI SENSIONALISME DALAM BERITA TELEVISI:}

PERSPEKTIF EVOLUSI BIOLOGI

berita yang dikemas dengan vivid

adalah penggunaan orang awam

untuk mengomentari opini publik, atau liputan politik yang menyoroti kehidupan pribadi politisi. Beritaberita demikian mengajak penonton untuk mengenali persoalan politik sebagai sesuatu yang dekat dengan keseharian. Pengemasan dengan gaya humaninterest menciptakan sebuh kesan kedekatan antara mereka yang diliput atau masalah yang disajikan dengan keseharian pentonton. Aspek lain dari Vivid Story telling yang juga diperkenalkan oleh Vettehen adalah teknik penggunaan kamera secara close up. Kajian Vettehen ini merupakan sebuah terobosan dalam studi mengenai sensasionalisme karena darinya kita menyadari bahwa sensasionalisme bukanlah hanya soal konten melainkan juga teknik produksi. Dengan ini kita bisa memahami ada dua level sensasionalisme dalam produksi televisi, yakni konten sensasional dan produksi yang sensasional. Vettehen menggambarkan perbedaannya dalam tabel di bawah.

\begin{tabular}{|c|c|}
\hline Sensational content features & Sensational production features \\
\hline $\begin{array}{l}\text { Sensational story topic } \\
\text { Embedded sensationalism } \\
\text { Sensational pictures } \\
\text { - Individual case histories } \\
\text { Interviews with laypersons }\end{array}$ & $\begin{array}{ll}\text { - } & \text { Number of camera shots } \\
\text {. } & \text { Mecorative editing techniques } \\
\text { : Sound effects } \\
\text { : Story length } \\
\text {. Eyewitness camera } \\
\text { Close-ups of human faces }\end{array}$ \\
\hline
\end{tabular}

Kleemans, Mariska \& Hendriks Vettehen, Paul. (2009). Sensationalism in television news : a review. Journal of Housing and The Built Environment.

Serangkaian studi telah menunjukkan dampak dari fitur produksi yang sensasional terhadap suka atau tidak sukanya penonton terhadap konten yang disajikan. Studi Vettehen, Koos Nuijten, dan Alerd Petters (2008), adalah salah satunya. Studi mereka memeriksa sejauh apa pola produksi sensasional mampu menimbulkan rangsangan terhadap penontonnya. Mereka menguji variabel produksi sensasional seperti on set music, decorative editing 
technique, story lenght, eyewitness

camera, close up of human face dan

decorative editing technique. Temuan

studi ini secara umum memvalidasi

asumsi-asumsi yang terdapat

dalamfitur-fitur produksi sensasional

seperti tertera dalam tabel di atas.

Temuan paling menarik dari studi tersebut adalah beberapa fitur produksi sensasionalisme terbukti menimbulkan rangsangan terhadap penonton dan beberapa lainnya tidak. Salah satu yang terbukti menemukan korelasi positif adalah dramatisasi berita. Lepas sebuah berita merupakan tema ekonomi, politik, atau olahraga, studi ini menujukkan kala ia dikemas dengan pendekatan sudut pandang human interest, ia menimbulkan dampak yang lebih kuat dalam memori penonton ketimbang yang tidak.Begitu juga halnya dengan penggunaan eyewitnesed camera dan layperson (orang awan) terbukti mampu menarik perhatian penonton lebih besar ketimbang berita yang tidak dikemas dengan cara demikian.

Di sisi yang lain, penggunaan musik on set music (musik yang mengiringi berita) dan durasi cerita yang lebih panjang tidak menunjukkan korelasi positif dengan tingkat perhatian penonton. Menurut Vettehen, dkk, terkait dengan on set music temuan studi mereka mesti diperiksa lebih jauh lagi dalam hubungannya dengan genre musik yang terdapat di dalamnya. Bisa jadi korelasi postif ditemukan bila musik yang digunakan untuk mengiringi berita memiliki tempo cepat, seperti dansa (120 denyut/detik), sesuatu yang jarang kita temukan dalam berita. Sayangnya, studi ini tidak mengantisipasi hal itu.Pengujian lebih lanjut juga kian urgen kala temuan terbaru menunjukkan bahwa tempo dan genre dalam musik mampu 


\section{MEMAHAMI SENSIONALISME DALAM BERITA TELEVISI:}

PERSPEKTIF EVOLUSI BIOLOGI

mempengaruhi gairah fisiologis jauh perlu dilakukan untuk menguji

(Potter \& Dillman Carpentier, 2005). $\quad$ hubungan usia dengan variabel durasi

Sedangkan temuan Vettehen

bahwa durasi cerita tidak

berhubungan dengan gairah

emosional bertentangan dengan

temuan Lang,Shin, Bradley, dkk.

(2005). Dalam studi Lang, durasi

berita berefek positif pada gairah

fisiologis dan waktu yang dihabiskan

untuk menonton sebuah berita

Namun,Lang, Shin, Bradley, dkk.

juga menyimpulkan bahwa secara

umum, durasi cerita tampakkurang

berpengaruh pada pemirsa yang lebih

tua dibandingkan dengan pemirsa

yang lebih muda.Tidak ditemukannya

korelasi positif antara durasi berita

dengan minat menontondalam

penelitian Vettehen jugapaling

banyak terjadi pada informan dengan

usia 40-an. Dengan kata lain, meski

korelasi negatif terjadi pada

responden usia muda, penelitian lebih berita.

Terakhir, studi Vettehen

menemukan bahwa gerakan zoom-in tidak terkait dengan rangsangan emosional yang dialami oleh pemirsa.Temuan ini berbeda dengan studi sebelumnya yang dilakukan Grabe et al. (2001). Studi tersebut menemukan korelasi positif antara peningkatan gairah memperhatian dengan teknik kamera close up pada wajah. Perbedaan ini menarik untuk ditelusuri lebih jauh. Studi lebih lanjut perlu dilakukan misal dengan cara mengujikan variabel ini dengan gender dan usia yang responden yang berbeda untuk menemukan kesimpulan yang lebih menyakinkan.

Meski beberapa variabel produksi sensasionalisme dalam studi-studi yang kami paparkan di atas belum secara menyakinkan 
menunjukan pengaruhnya, namun

beberapa diantaranya telah

menemukan bukti yang kuat.

Dramatisasi dan pengguaan kamera

bergaya "eyewitness" terbukti mampu

menciptkan efek sensasional yang

kuat pada penonton. Dari dua hal ini

saja, serangkai studi tersebut berhasil

memvalidasi dua hal penting.

Pertama, otak manusia bekerja secara

universal sebagaimana diasumsikan

oleh Limited Capacity Model. Hal ini

terlihat dari beberapa kajian yang

secara konsisten menemukan efek

yang sama dari konten maupun fitur

produksi sensasional terhadap

rangsangan yang dihasilkan oleh

manusia. Kedua, teknik produksi

sensasional bisa diekstrak pada

berbagai berita yang secara natural

bukan berita survival insting dan

mampu menciptakan sensasi yang

sama kuatnya sebagaimana digambarkan dalam studi-studi yang

telah kami paparkan di atas.

\section{KESIMPULAN}

Beberapa hal dapat disimpulkan dari paparan dalam artikel ini. Pertama, paparan teoritis maupun empiris yang kami sajikan dalam penelitian ini menunjukkan bahwa hipotesis awal yang kami usung bisa dipertahankan. Cara kerja otak manusia dan insting dasar yang dibawa sejak evolusi, terbukti linier dengan konten dan model produksi sensasional. Inilah mengapa senasionalisme terus menjadi resep ampuh bagi jurnalisme yang didorong oleh kehendak mengakumulasi keuntungan. Kendati demikian, catatan perlu diberikan. Jika topik berita sensasional (berita mode of survival) secara menyakinkan punya dampak yang kuat pada penonton, maka tidak halnya dengan model produksi sensasional. Hal ini 
berkaitan dengan kesimpulan kedua kami, yakni kala model produksi senasional coba mengekstrak elemen sensasionalisme dan memperluasnya pada topik-topik lain tidak semua fiturnya bekerja. Kecuali penggunaan kamera sudut pandang pertama, dramatisasi, dan pelibatan orang awan dalam pemberitaan, lainnya tidak terbukti secara empiris punya pengaruh. Karena itu, kami mengusulkan untuk melakukan penguji lebih jauh terkait dengan pengguna close up, on set music, "panjang durasi cerita" dan dampaknya terhadap sensasi di kepala penonton. Penelitian semacam ini akan sangat berguna untuk terus mengakumulasi pengetahuan kita mengenai jurnalisme sensasional dan dampaknya.

Hal lain, terkait dengan tujuan penelitian ini sebagai telah kami sampaikan dalam latarbelakang, yakni untuk mendorong tercipta kurikulum literasi media yang efektif guna menangkal pengaruh jurnalisme sensasional di kalangan publik setidaknya satu temuan penting bisa diajukan di sini. Literasi media yang kita usung dalam rangka mendekonstruksi berita sensasional tidak cukup hanya dengan memberi publik pengetahuan mengenai jenisjenis atau topik-topik berita senasional. Fakta bahwa elemen sensasionalisme bisa diekstrak pada topik lain mesti membuat kita sadar pentingnya menambahkan subjek mengenai model produksi sensasional dalam kurikulum literasi media kita. Dengan kata lain, menjelaskan bagaimana dampak dramatasi secara visual maupun audio pada cara kerja otak kita. Dengannya, publik punya pengetahuan dan keterampilan yang cukup untuk memproses secara logis 
dan kritis kala menerima stimuli

pemberitaan sensasional.

\section{DAFTAR PUSTAKA}

Arief, Yovantra (2017, 11 Juli). Politaiment Gubernur Jakarta Baru. Amatan. Retrieved 9 Juli, 2020, dari Remotivi: https://www.remotivi.or.id/amata n/429/politainment-gubernurbaru-jakarta

Berkowitz, \& Gobetz, S. \&. (1993;1992). Explicating sensasionalism in television News. Nijmegen, Netherlans: Tandem Felix.

Bradley, S. D. (2007). Dynamic, embodied, limited-capacity attention and memory: Modeling cognitive processing of mediated stimuli. Media Psychology, 9(1), 211-239.

Bradley, M. M., Codispoti, M., Cuthbert, B. N., \& Lang, P. J. (2001). Emotion and motivation I: Defensive and appetitive reactions in picture processing. Emotion, 1(3), 276-298.

Bradley, M. M., Cuthbert, B. N., \& Lang, P. J. (1990). Startle reflex modification: Emotion or attention? Psychophysiology, 27(5), 513-522.

Bradley, M. M., \& Lang, P. J. (1994). Measuring emotion: The selfassessment manikin and the semantic differential. Journal of Behavior Therapy and
Experimental Psychiatry, 25(1), 49-59.

Cacioppo, J. T., Gardner, W. L., \& Berntson, G. G. (1997). Beyond bipolar conceptualizations and measures: The case of attitudes and evaluative space. Personality and Social Psychology Review, 1(1), 3-25.

Cacioppo, J. T., Gardner, W. L., \& Berntson, G. G. (1999). The affect system has parallel and integrative processing components: Form follows function. Journal of Personality and Social Psychology, 76(5), 839-855.

Cacioppo, J. T., Tassinary, L. G., \& Berntson, G. G.2000). Handbook of psychophysiology. Cambridge: Cambridge University Press.

Davis, H., \& McLeod, S. L. (2003). Why humans value sensational news: An evolutionary perspective. Evolution and Human Behavior, 24, 208-216.

Desimone, R., \& Duncan, J. (1995). Neural mechanisms of selective visual attention. Annual Review of Neuroscience, 18(1), 193-222.

Grabe, M. E., Lang, A., \& Zhao, X. (2003). News content and form. Implications for memory and audience evaluations. Communication Research, 30, 387-413.

Grabe, M. E., Zhou, S., \& Barnett, B. (2001). Explicating sensationalism in television news: Content and the bells and whistles of form. Journal of 
Broadcasting \& Electronic Media, 45, 635-655.

Harahap, Arifin S. 2014. Dampak Berita Kriminal di TV. Jurnal Komunikologi Volume 11 no 2, September 2014.

Handy, T. C., Hopfinger, J. B., \& Mangun, G. R. (2001). Functional neuroimaging of attention. In R. Cabeza \& A. Kingstone (Eds.), Handbook of functional neuroimaging of cognition (pp. 75-108). Cambridge, MA: The MIT Press.

Haryatmoko. 2007. Etika Komunikasi: Manipulasi Media, Kekerasan, dan Pornografi. Yogyakarta: Kanisius

Kastner, S., \& Ungerleider, L. G. (2000). Mechanisms of visual attention in the human cortex. Annual Review of Neuroscience, 23, 315-341.

Kitley, Philip. 2000. Konstruksi Budaya Bangsa di Layar Kaca. Jakarta: Institut Studi Arus Informasi

Kleemans, Mariska \& Hendriks Vettehen, Paul. (2009). Sensationalism in television news : a review. Journal of Housing and The Built Environment.

Lang, A. (2000). The limited capacity model of mediated message processing. Journal of Communication,50(1), 46-70.

Lang, A., Bradley, S. D., Sparks, J. V., Jr, \& Lee, S. (2007). The motivation activation measure (MAM): How well does MAM predict individual differences in physiological indicators of appetitive and aversive activation? Communication Methods and Measures, 1(2), 113-136.

Mulyadi, Urip (2015).Tabloidisasi Pemberitaan Mengenai Pemilu Presiden 2014 Pada Program Berita "Headline News" Metro $T V$ ”. Jurnal Makna. Vol. 5 no. 2, Agustus 2014-Januari 2015

Puji Saputri, Yuweni (2019). Analisis Isi Sensasionalisme Berita Kriminal: Studi Kasus Program INEWS dan KOMPAS SULSEL. Jurnal Pranata Edu. Volume 1 No 1, Maret 2019

Santana K, Septiawan (2005). Jurnalisme Kontemporer. Yayasan Obor: Jakarta

Sthepens, Michell (2007). A History of News. Oxford University Press: New York

Treisman, A. M., \& Gelade, G. (1980). A feature-integration theory of attention. Cognitive Psychology, 12, 97-136.

Uncapher, M. R., Thieu, M., \& Wagner, A. D. (2016). Media multitasking and memory: Differences in working memory and long-term memory. Psychonomic Bulletin \& Review, 23(2), 483-490.

Uribe, Rodrigo \& Gunter, Barrie. (2007). Are 'Sensational' News Stories More Likely to Trigger Viewers' Emotions than NonSensational News Stories? A Content Analysis of British TV 
News. European Journal of Communication. 22. 10.1177/0267323107076770.

Shoemaker, P. J. (1996). Hardwired for news: Using biological and cultural evolution to explain the surveillance function. Journal of Communication, 46(3), 32-47.
Slattery, K. L., \& Hakanen, E. A. (1994). Sensationalism versus public affairs content of local TVnews: Pennsylvania revisited. Journal of Broadcasting \& Electronic Media, 38, 205-216. 